\title{
RACE, NATION, AND RESISTANCE TO STATE SYMBOLIC POWER IN RWANDA SINCE THE 1994 GENOCIDE 1
}

\author{
Aliza Luft \\ Department of Sociology \\ University of California, Los Angeles \\ Susan Thomson \\ Department of Peace and Conflict Studies \\ Colgate University
}

${ }^{1}$ This paper is forthcoming in a special issue on the Global Historical Sociology of Race and Racism in Political Power and Social Theory, Volume 38, 105-134. 


\begin{abstract}
The social categories "Hutu" and "Tutsi" have long been central to Rwandan politics, though never more so than during the 1994 genocide, when they formed the ultimate divide: kill (Hutu) or be killed (Tutsi). Since then, the Rwandan government has sought to eliminate these categories and replace them with a new, national identity category of "Rwandan." This chapter draws on theories of state symbolic power and legibility to analyze how top-down projects of remaking Rwandans are being received from below. Specifically, we examine ordinary Rwandans' responses to gacaca, a community justice practice central to the state's National Unity and Reconciliation Program, and find Rwandans resent efforts to "unmake race" in favor of "nation" because the state's account of genocide in gacaca does not allow them to sincerely express their experiences; it activates traumatic pasts for what they feel is superficial national reconciliation; and it detracts from their material needs. These findings highlight the importance of distinguishing between compliance and conviction in research on state efforts to transform civilian subjectivities. They also suggest directions for further research. Namely, future research on state symbolic power should attend to how individual experiences with violence mediate topdown efforts at remaking civilian subjectivities, to how different forms of governance shape civilian resistance to state categorization and classification projects, and to what kinds of interests are likely to motivate people to alter their self-perceptions. We conclude by arguing for more work on state race and nation-making from the perspectives of its targets.
\end{abstract}

Keywords: Race; ethnicity; nation; symbolic power; genocide; Rwanda 


\section{INTRODUCTION}

During the 1994 Rwandan genocide, race was the central social category separating who would live from who would die. As a result, since the end of the genocide and since taking power in July 1994, the ruling Rwandan Patriotic Front (RPF) has introduced a variety of nationmaking initiatives intended to create a single Rwandan identity that eschews ethnic categories (Burnet, 2012; Longman, 2017; Purdeková, 2016; Thomson, 2013). ${ }^{2}$ Chief among these is the National Unity and Reconciliation Program, which requires Rwandans to participate in various activities, such as the neo-traditional gacaca community justice trials, in order to construct the "new" Rwandan nation. Hence, in gacaca as well as other National Unity and Reconciliation activities, Rwandan's identities as Hutu, Tutsi, or Twa are negated in favor of the revamped national identity of "Rwandan-ness." 3 This is a tall order in a country where Hutu extremists deployed the machinery of the state to target Tutsi for death (Fujii, 2009; Straus, 2006). Hence, our chapter analyzes how ordinary Rwandans have responded to government attempts at transforming social categories and their content since the 1994 genocide. ${ }^{4}$

To do so, we review existing literature on state symbolic power and legibility to identify the conditions under which top-down efforts at remaking civilian subjectivities are theorized to

\footnotetext{
2 We discuss our use of the terms "race" and "ethnicity" on pp. 5-6, below.

${ }^{3}$ Though this chapter focuses primarily on the Hutu/Tutsi cleavage and its salience for ordinary Rwandans, it is worth noting that the attitudes and behavior of both Hutu and Tutsi, regardless of economic class, are prejudicial toward members of the minority Twa, representing historically and today just one per cent of the Rwandan population (Thomson, 2018, p. 24). Hutu and Tutsi alike have systematically scorned Twa, based on their physical stature as forest-dwelling pygmies, denying them basic courtesies of community membership such as sharing food and drink, participating in church life, or intermarriage.

${ }^{4}$ We conceptualize "ordinary Rwandans" as the non-elite and largely peasant citizenry, constituting some $80 \%$ of the population (Newbury \& Newbury, 2000, p. 834). This is in contrast to those who hold formal political power as a member of the political elite or individuals engaged as agents of the state (police officers, civil servants, military personnel, and local government authorities, and so on) (Thomson, 2013, p. 8). It is also, of course, in contrast to the "Rwandan" national category that the state is trying to naturalize and which we examine in this chapter.
} 
succeed. Next we examine the history of social category politicization in Rwanda, focusing specifically on the Hutu and Tutsi categories, from pre- to post-colonialism and genocide. Where possible, we discuss civilians' responses to top-down efforts at changing these categories and their content during these time-periods. We then introduce our data and methods, followed by an analysis of ordinary Rwandans' perspectives on gacaca, which ostensibly has many of the ingredients required to transform individual subjectivities: traditional legitimacy, mandatory and widespread participation, and punishments for those who resist.

Yet our bottom-up analysis finds this nationalizing project is failing. Moreover, it is failing for three reasons. First, gacaca requires Rwandans to discuss their experiences during the genocide in terms of a state-mandated narrative that frames all Hutu as perpetrators and all Tutsi as victims. This does not square with ordinary Rwandans' experiences during the genocide nor the civil war that preceded and overlapped with it, fostering anger at this forced suppression of truth. Second, gacaca activates painful memories for Rwandans, many of whom would rather not revisit traumatic pasts for what they feel is superficial - and disrespectful - state-mandated change. Third, gacaca takes time and money away from ordinary Rwandans who are more concerned with fulfilling their basic needs than meeting what they believe are contrived topdown goals of national unity. Each of these findings speaks to the importance of distinguishing between compliance, which is common in Rwanda, and conviction, which is not, when researching state-led efforts to remake civilian subjectivities.

The results of our bottom-up analysis suggest new directions for future research. Specifically, they call attention to how individual experiences with violence may interfere with top-down projects to construct new social categories when these projects do not adequately 
address past wrongs. They also suggest that strong state capacity and civilian compliance, often emphasized in the research on war and nation-making, is insufficient to bring people together under the label of a unifying category, as genocide also requires strong state capacity and civilian compliance but has divisive, as opposed to integrative, consequences. Our results further indicate the need for research on state symbolic power to better distinguish between compliance and conviction in different political regimes as different forms of governance may affect the kinds of resistance to state legibility projects that can emerge. Finally, our results indicate that it is important for new social categories to resonate with ordinary people's interests rather than run counter to them. Additional work is required on how civilians' interests influence not only their likelihood to comply with state categorization projects but also their likelihood to believe in these projects and alter their self-perceptions in turn. We conclude the chapter by calling for more research on state symbolic power and legibility that considers the subjective experiences of those whose subjectivities the state is trying to change.

\section{TERMINOLOGY}

Throughout this chapter, we use the terms race and ethnicity in keeping with how these categories are and have been practiced by Rwandans at different moments in time. During colonialism, for example, the words "origin - people - race" (afkomst - volksstamm - ras) and then "Hutu,"“"Tutsi," or "Twa" were marked on identity cards and kept as a state-imposed "racial" category in the post-colonial period. Similarly, the Bahutu Manifesto, a political document produced in 1957 that called for Hutu political dominance and solidarity and Tutsi disenfranchisement, used the term "race" throughout (see p. 110). Thus, our emphasis is on 
practical rather than analytical categories (Brubaker, 2002, 2013; Wacquant, 1997). Where Rwandans use(d) the word "race," we do, too. Where they use(d) the word "ethnicity," we do as well. Presently, although the terms "Hutu" and "Tutsi" are illegal in Rwanda unless otherwise stated by the government, the word used to describe them is "ethnicity." Accordingly, Article 2 in Law No 18-2008 of 23/07/2008 Relating to the Punishment of the Crime of Genocide Ideology outlaws thoughts and actions aimed at "exterminating or inciting others to exterminate people basing on ethnic group, origin, nationality, region, color, physical appearance, sex, language, religion or political opinion." 5 The word race is not mentioned once. Similarly, when discussing the violence of the past, Rwandan president Paul Kagame regularly deplores "ethnic discrimination" and "ethnic violence" but not "racial discrimination" or "racial violence." As a general rule, we therefore use the term "race" when discussing pre-genocide politics and the 1994 genocide in Rwanda and "ethnicity" when discussing post-genocide politics, even though, in all cases, the terms reference the Hutu and Tutsi social categories.

\section{SYMBOLIC POWER FROM ABOVE AND BELOW}

Race, nation, and other social identity-making projects can both constitute and reinforce state power (Hacking, 1986; Lam, 2011; Loveman, 2005, 2014; Scott, 1990, 1998; Starr, 1987, 1992; Tilly, 2004; Wacquant, 2002). ${ }^{6}$ As a result, states often construct new categories and classification practices as a way to naturalize their rule. Defined by Bourdieu as "symbolic power," this ability to refashion self-understandings by implementing new "categories of vision

\footnotetext{
5 Emphasis ours.

${ }^{6}$ Following Bailey et al. (2018, p. 744, ff. 1), we use the term "state" in this paper to refer to "state institutions at various levels of government."
} 
and division" facilitates state legitimacy by making social distinctions appear natural (1989, 1991, 1999, 2000). Insofar as states are able to naturalize how the social world is perceived and organized, they can control access to the opportunities and pro-visions they provide. Hence, states engage in diverse projects to construct social categories and classification schemes and generate boundaries based on these divisions. When social differences become perceived as natural differences, and when the delivery of privileges or penalties are tied to these differences, states can preserve social orders that benefit them as dominant. To the extent that states are able to construct social reality, they simultaneously become able to establish themselves as legitimate.

There are multiple mechanisms through which states can accumulate symbolic power so as to naturalize the social orders that establish their rule. Loveman (2005, pp. 1662-1664), for example, proposes four: states can accumulate symbolic power by (1) innovating new administrative practices; (2) imitating existing ones; (3) co-opting traditional practices; and (4) usurping the administrative practices of authorities or organizations outside the state. Other scholars, though not always drawing on the language of symbolic power explicitly, suggest that states can naturalize social boundaries and hence, their own authority, by including categorical distinctions in law and policy, thus requiring that individuals make use of them when reporting information. Such practices reify social categories while naturalizing the state's power by encouraging civilians to think and act using the state's categories (Anderson, 1991; Bailey, 2008; Bailey \& Fialho, 2018; Francis-Tan \& Tannuri-Pianto, 2015; Goldberg, 1997, pp. 27-58; Kertzer \& Arel, 2002; Lieberman \& Singh, 2012, 2017; Loveman, 2014; Star \& Lampland, 2009; Starr, 1992). Still others note how state practices of tying categorical distinctions to the allocation of privilege or punishment naturalizes those same distinctions by endowing them with material 
consequence (Bailey \& Fialho, 2018; Bailey, Fialho, \& Loveman, 2018; Brubaker, 1996; Cornell \& Hartmann, 1998; Davis, 1991; Jenkins, 1997; Marx, 1997; Mora, 2014; Nagel, 1995). ${ }^{7}$ As a result, seemingly benign administrative practices that rely on naming, demarcating, and defining categories of people often have the result of producing those very kinds in the first place (Hacking, 1986).

Despite the important contributions of this work, there is a tendency in research on symbolic power to focus on state practices from above to the occlusion of societal influences from below (Emigh, Riley, \& Ahmed, 2016, 2019, n.d.; Mora, 2014; Rodríguez-Muñiz, 2017, 2021). This is so even as most scholarship explicitly recognizes that when states seek to extend or assert their administrative capacity, there is likely to be conflict over "the boundaries and nature of state involvement" in new domains of social life (Loveman, 2005, p. 1658). Moreover, although examples of resistance can be found in numerous studies (e.g., Carroll, 2006; Cohn, 1987; Curtis, 2001; Mora, 2014; Rodríguez-Muñiz, 2017), the analysis still tends to privilege the state's perspective - that is, frustrated efforts by state authorities to implement new categories of "vision and division." Loveman's (2007) study of the "war of the wasps" in nineteenth-century Brazil, when the rural poor refused to cooperate with civil registration practices, and Diamant's (2001) analysis of unsuccessful attempts to implement civil marriage registration in Maoist China, present rare exceptions. Meanwhile, Malkki’s (1995) comparison of Burundian Hutu refugees in Tanzania presents a unique example of the construction of a new national category outside the boundaries of the state.

${ }^{7}$ Of course, laws and policies often go hand in hand with the allocation of opportunities and resources. 
Similarly, although recent years have witnessed increased attention to bottom-up influences on state administrative practices (Emigh et al., 2016, 2019, n.d.; Mora, 2014; Paschel, 2016; Rodríguez-Muñiz, 2017), we still have little qualitative data on how those subject to state efforts at accumulating symbolic power feel about these practices and what facilitates or impedes these projects from their perspectives. For example, Mora (2014) examines the construction of the term "Hispanic" in the United States and illuminates how key stakeholders such as bureaucrat, media, and activist organizations collaborated - though with different intentions and after some initial conflict - to produce what became a new, pan-ethnic, identity category. Likewise, Rodríguez-Muñiz (2017) examines how non-state leaders, in his case the Rhode Island Complete Count Committee, enabled the state through consent-building activism to produce new forms of social knowledge concerning Latino demographic growth in the 2010 US census. Rodríguez-Muñiz documents resistance along the lines of apathy, frustration concerning the categories used, fear of state surveillance, and even a boycott by the National Coalition of Latino Clergy and Churches, but the emphasis of his study is on non-state leaders' efforts to combat this noncompliance, not why noncompliance existed in the first place (see also Rodríguez-Muñiz, 2021, Chapter 2). Both are excellent contributions to understanding how civilians influence state efforts at institutionalizing social categories; however, it is unclear how - or even whether - from the perspectives of those subject to these actions, the outcomes of state and non-state collaborations generated a shift in self-understandings from below.

Recently, Bailey et al. (2018) and Bailey and Fialho (2018) provide evidence of changing racial subjectivities in Brazil in response to race-targeted state policy. Drawing in both cases on two waves of national survey data, these studies provide rare evidence that states' use of racial 
categories to allocate resources and opportunities (in this case, affirmative action in government hiring and university admissions) can alter self-understandings. Yet here, too, we lack qualitative data that explain these results from civilians' perspectives and are presented with a positive case of top-down success. In contrast, this chapter presents a failed case from civilians' perspectives of state efforts to remake race and nation despite heavy-handed attempts by the state to tie the remaking of social boundaries to the allocation of punishment via a traditional practice modified for the present.

Specifically, our contribution to this debate is an analysis of how ordinary Rwandans feel about gacaca, a mainstay of the contemporary Rwandan National Unity and Reconciliation project, and its goal of eliminating the Hutu and Tutsi categories that have long been so salient in Rwandan politics. In so doing, the chapter extends theories of symbolic power by analyzing postgenocide Rwandan identity politics from below - that is, from the perspective of those subject to state efforts at constructing what it means to be "Rwandan"-and we consider this a negative case as our results suggest that the RPF's efforts to craft a singular national identity in Rwanda are failing. Further, the reasons why they are failing suggest that the particular experience of genocide is central to understanding why some identity categories may be especially "sticky" and harder to eliminate through top-down administrative practices, particularly when these are enforced through such a heavy, authoritarian hand that neglects civilians' actual needs from their perspectives.

\section{ON HUTU AND TUTSI AS POLITICALLY SALIENT CATEGORIES}


The meanings of the terms "Hutu" and "Tutsi" have changed throughout Rwanda's past, at times connoting more fluid social categories tied to one's occupation and place in the political hierarchy, and at other times connoting ideas about inherent biological difference (Mamdani, 2002; Newbury, 1998; Thomson, 2018, pp. 35-38). An understanding of why political elites Hutu and Tutsi - have instrumentalized these categories for political purposes matters for our argument, as it illustrates how colonial contact entrenched and essentialized the precolonial social categories of Hutu and Tutsi, which would eventually define the central cleavage of the 1994 genocide.

\section{Precolonial Labels and Colonial Influence}

At the time of colonial contact, in 1892, when representatives of the German government first arrived in the Great Lakes region to assess what use they might make of the land and its people, present-day Rwanda did not exist (Vansina, 2004, p. 176). Instead, there was a strict patronage system of Tutsi chiefs appointed by Tutsi kings known as Mwami who required Hutu to labor for them in exchange for the right to land and cattle. Under Mwami Kigeli IV Rwabugiri's (c. 1860-1895) rule, all subjects were classified as Hutu and the only way they could shed this status was by accumulating wealth - a difficult task given its concentration in the hands of Tutsi rulers. Upon making contact with the Tutsi representatives of the royal court, the Germans lent support to Mwami Rwabugiri's efforts to capture and command peripheral regions of the territory that would become modern-day Rwanda under his control. Thanks to the Germans, Rwabugiri now had access to guns and had learned new military techniques. Rwabugiri then focused his military attention on the Hutu-led lineages in the north that earlier 
had thwarted Tutsi royal efforts to conquer them. These conflicts for land and people were often violent, with Rwabugiri deploying "all available means to bring lineage heads under his control" (Thomson, 2018, p. 43). The result was the solidification of a centralized and hierarchical sociopolitical structure designed for maximum administrative control with elite Tutsi at the top as indirect rulers.

Additionally, however, and to further secure its indirect rule of Rwanda, the Germans institutionalized Hutu and Tutsi as distinct racial categories, along with a new classification scheme that attributed inherent qualities to them (Vansina, 2004, p. 3). The colonists, who saw themselves in the tall, elegant, fairer-skinned Tutsi with narrow, northern European-type facial features, classified Tutsi as "white Africans" who had brought the sophisticated structure of the Tutsi royal court from the Roman colonies of North Africa to Rwanda, much to the strategic delight of the royalists (Des Forges, 1995,p.44). In contrast, and on the advice of court oral historians known as abiru, the colonists classified Hutu as natural cultivators, evidenced in their short, husky builds, dark skin, and broad, flat facial features. In efforts to rationalize their own biases, the Europeans ignored phenotypic variations that did not accord with their artificially neat classification scheme of sophisticated Tutsi and simple but hardworking Hutu. All Tutsi were regarded as natural leaders given their presumed innate intelligence, while all Hutu, given their presumed submissive dispositions, were obvious subjects. This framing would come to define Rwandan political culture, with elite Tutsi perceiving themselves as natural leaders whose task was to govern and provide for their Hutu subjects (Des Forges, 1995, p. 45; Thomson, 2018, pp. 41-43; Vansina, 2004, pp. 175-176). 
Later, when Belgium inherited Rwanda from Germany under a League of Nations

mandate in 1919, these social and political divisions were maintained and even further ossified, drawing on existing practices of customary labor, much to the delight of Tutsi royalists who continued their violent reign (Vansina, 2004, p. 165). For example, the Belgians introduced the coffee crop and institutionalized a forced labor corvée system known as ubuhake. Many Hutu submitted to the demands of the Belgians, as they offered physical protection from warring elite Tutsi lineages, leading to the formalization of Hutu and Tutsi as politically salient categories (126). Ubuhake also served to structure relationships between land-owning herders (usually Tutsi) to give cattle to their clients (usually Hutu) in usufruct in exchange for labor, land, and crops. This was an additional burden to the precolonial practice of uburetwa, through which rural Rwandans had to provide their labor in service to their local chieftain. Finally, the Belgians introduced racial identity cards to maintain this labor system and taught the fabricated history of superior Tutsi foreigners and inferior Hutu peasants in schools (Thomson, 2020, pp. 260-264). ${ }^{8}$

\section{Political Independence and the Question of Race}

In the late 1950s, an educated and aspirant Hutu counter-elite started mobilizing against Belgian colonialists and their Tutsi administrators, frustrated by their lack of social and political mobility due to their status as Hutu (Newbury, 1988, p. 197; Lemarchand, 1970, p. 139). Tutsi elites likewise mobilized against Belgian colonists, though their claims emphasized a cleavage between Belgians as Europeans and Rwandans as Africans in a hope to maintain political

\footnotetext{
8 Importantly, we cannot say with certainty that these colonial racialization practices led all ordinary Rwandans to perceive themselves in these ways as we lack evidence that speaks to their subjective experiences during these timeperiods. That said, the fact that an elite Hutu resistance movement would mobilize years later suggests they were not entirely successful, as these Hutu refuted parts of the colonial classification scheme (e.g., that Hutu are natural subjects) while maintaining others (e.g., that Tutsi are foreigners to Rwanda).
} 
dominance with independence. Yet Hutu elites, as expressed in the "Bahutu Manifesto," felt the primary problem was Tutsi dominance and sought to maintain the formal classification practices of Belgian colonists, such as racial identity cards, as a way to establish democracy as majority rule. The colonial racialization of Hutu and Tutsi categories had clearly been internalized by Hutu elites at this point, who perceived it necessary to "count" race in order to address past discrimination rather than to eliminate racial categories altogether. ${ }^{9}$ The manifesto explained,

...In order to monitor this race monopoly, we are strongly opposed, at least for the time being, to removing the labels "Matutsi," "Mahutu," and "Matwa" from identity papers....race [is] the marker of oppression and therefore of [Hutu] liberation. ${ }^{10}$

Following this, a Hutu political movement was formed to pursue the objectives outlined in the manifesto and in November 1959, the Hutu revolution began (Newbury, 1988, p. 192). By the time it ended three years later, the Belgian colonists had left, the Tutsi monarchy was overthrown, and Hutu held control of the state. A United Nations report from March 1961 described the situation as "a racial dictatorship" and explained "the developments of the last eighteen months have consisted in the transition of one type of oppressive regime to another" (cited in Lemarchand, 1970, pp. 194-95). To escape the Hutu monopoly, over 300,000 Tutsi fled abroad, mostly to Uganda but also to Burundi and the Democratic Republic of Congo (then known as Zaire).

\footnotetext{
${ }^{9}$ Again, we are unable to speak to ordinary Rwandans' perspectives without sufficient qualitative evidence that can tell us how they felt about, in this instance, elite Hutu racial projects.

${ }^{10}$ United Nations Trusteeship Council (UNTC), Report of the United Nations Visiting Mission to Trust Territories in East Africa, 1957, on Ruandi-Urundi (T/1346): Annex I: "Manifesto of the Bahutu." Note on the Social Aspect of the Indigenous Racial Problem in Ruanda (UN-doc: T/1402; New York, 1958), pp. 39-42.
} 
The next 30 years would witness on-again, off-again conflicts between different factions of Hutu elite, in particular Hutu in South-Central and Northern Rwanda, while there lacked an effective Tutsi political opposition during this same time-period as a result of the Hutu revolution. The main political cleavage in Rwanda was intra-Hutu and regional, culminating in the 1973 coup d'état of Rwanda's first postcolonial Hutu President, Grégoire Kayibanda, by Hutu defense minister General Juvénal Habyarimana. Meanwhile, Rwandan Tutsi refugees in Uganda began to organize a militant group called the Rwandan Patriotic Front (RPF) with the goal of returning to Rwanda to reestablish control (Gourevitch, 1996).

Simultaneously, Tutsi who remained in Rwanda after the revolution were subject to systematic discrimination on the basis of race (Des Forges, 1999, p. 40). Racial quotas were implemented by Kayibanda in schools, civil service, and the private sector, limiting Tutsi to $9 \%$ in each to match their overall percentage in the population (Fujii, 2009, p. 71). Under Habyarimana, these quotas remained and regional quotas were introduced as well, paradoxically creating openings for some central and southern Tutsi to benefit. For the first several years of Habyarimana's rule, order was maintained, and the threat of physical violence rooted in racial division was low. In general, and regardless of their racial identity or economic class, Rwandans remember this as a good and peaceful time (Reyntjens, 2018; Prunier, 1995). Unfortunately, it was short-lived as the extensive administrative reach of the government into the lives of ordinary Rwandans was unable to deliver the promised goods: "peace, tranquility and the space to do what [is needed] to do in order to survive" (Desrosiers, 2020, p. 573).

Elite Reliance on Racial Difference as a Political Strategy 
In the late 1980s and early 1990s, international pressures to democratize forced elite Hutu to share political power with elite Tutsi for the first time since independence. ${ }^{11}$ At the same time, a storm of structural shocks as global commodity prices plummeted led the Habyarimana government to once again publicly deploy ideologies of racial difference to frame all Tutsi as enemies of the state in response to invading RPF rebels, who launched a civil war from Uganda in October 1990 (Desrosiers, 2014; Newbury, 1998). By leaning on race to mobilize Hutu as a single political category, Habyarimana was hoping to consolidate support across the political spectrum in the face of growing threats to his rule. Racist violence was promoted in magazines, newspapers, political pamphlets, and state-run radio propaganda, which called all Hutu civilians to stand guard and remain vigilant against all Tutsi, including neighbors and friends. State propaganda commanded Hutu to remain loyal to their racial brothers and sisters in framing Tutsi inside Rwanda as allies of the RPF and enemies of the state (Thomson, 2020).

Simultaneously, the Habyarimana government tolerated, and in some instances, ordered its militias to murder Tutsi civilians. These state-led murders reminded Hutu civilians of the ever-present threat of the RPF, intentionally deployed by the government to invoke the specter of a return to the precolonial violence of the Tutsi royal court, not to mention Tutsi indirect rule under colonialism. The message was plain: all Hutu had to remain vigilant to the threat posed by their Tutsi neighbors, colleagues, friends, and family, lest they lose power and become subjects once more. But, as we review with evidence on the subjective experiences of ordinary Rwandans, not all Hutu believed these messages, leading to significant variation in how they responded to the call to kill their Tutsi neighbors during the genocide a few years later.

${ }^{11}$ Concerning the influence of international donors in "aiding violence" in Rwanda, see Uvin (1998). 


\section{The 1994 Rwandan Genocide}

At 8:24p.m. on April 6, 1994, President Habyarimana was assassinated by two surface-toair missiles upon a return flight home from Tanzania. Almost immediately, political adversaries of the Habyarimana government, as well as moderate judges, priests, journalists, and human rights activists, were murdered (Guichaoua, 2015). Almost all of them were Hutu elites, willing to share political power with the rebel, Tutsi-led RPF (Thomson, 2018, pp. 19-21).

Simultaneously, the RPF resumed its civil war and began to secure defensive positions around the country, including the State House in the capital, Kigali (Fujii, 2009, p. 54). Civilians were not involved at this early stage, though rather quickly, the new order of the day became clear: Hutu were expected to kill, and Tutsi were to be killed. Over the next 100 days, government authorities, the military, a militia known as the Interahahmwe, and mostly Hutu civilians sought out and massacred 75\% of Rwanda's Tutsi population (Des Forges, 1999, p. 15).

Crucially, however, and despite the racist propaganda of extremists, rarely did Hutu civilians participate in the genocide because they believed this messaging. ${ }^{12}$ Rather, the timing, speed, and intensity of violence during the genocide varied from place to place, demonstrating that genocide was not a sudden outburst of racist hatred but instead was the result of complex individual choices made among a narrow set of kill-or-be-killed options that were informed by local social, economic, and political networks and the presence of government-sponsored militia.

For example, Hutu rarely killed alone. Much of the killing during the genocide was committed in militia-led groups of 10-15 people, known as igitero (mobs), demonstrating the significance of social group processes for participation in violence (Mironko, 2004, pp. 193-202;

\footnotetext{
12 On this point and for a summary of the scholarship linking dehumanizing propaganda to participation in genocide,
} see Luft (2019). 
Straus, 2006, pp. 26-28). Social ties, particularly ties to political power at the local level, as well as friends, family, and business groups, shaped how mobs were formed and who led the killing, while within-group dynamics meant that one or two individuals would kill while others cheered or supported the murderers (Fujii, 2009, pp. 17-21, 173-178). Moreover, communities where local leaders had close ties to the ruling political party, or the remnants of the interim government that governed during the genocide, were especially effective at organizing the killing. Where they refused, they were either arrested or killed and replaced with extremists (Des Forges, 1999, pp. 167, 367, 385; Luft, 2015, pp. 160-162). Occasionally, Hutu who killed in groups would save Tutsi when on their own (Fujii, 2009, p. 594; Luft, 2015, p. 160).

As a result, Straus (2006, p. 136) finds that Hutu most often killed Tutsi under duress from local military and political leaders, while Fujii (2009, pp. 95-98) finds that dense local ties and within-group social pressures explain why Hutu participated in the genocide. Luft (2015, pp. 157-160) likewise finds that vertical and horizontal pressures explain why Hutu killed Tutsi, and she finds that Hutu killed Tutsi when they lacked economic resources that could provide them with opportunities to resist. Finally, Luft (2015, pp. 162-164) finds that timing increased the likelihood that Hutu would kill Tutsi as they cognitively adapted to the act of murder, even as the same Hutu initially joined in the violence to save other Tutsi with whom they were close. Each of these findings suggests that rarely did Hutu civilians willingly participate in the genocide (at least, not at first) because they believed state propaganda and wanted to eliminate all Tutsi as a racialized threat. ${ }^{13}$

13 ff. 10. 
Moreover, participation at the local level did not always follow the neat divide of Hutu killers and Tutsi victims. Though certainly, the majority of killers were Hutu and the majority of victims were Tutsi, resistant Hutu were also often murdered while, occasionally, Tutsi participated in violence against other Tutsi to save themselves (Thomson, 2013, 2018). Yet other Hutu engaged in rescuing behaviors throughout the genocide (Fox \& Brehm, 2018; Thomson, 2018), while some, as mentioned above, saved Tutsi despite killing at other moments in time (Fujii, 2009; Luft, 2015). Many Hutu refused the call to participate in genocide altogether (Straus, 2004). Despite top-down efforts to divide the population along a clear racial boundary with life-or-death consequences for resistance, people often behaved in ways that countered the state's goal of mobilizing all Hutu to kill all Tutsi (Luft, 2015).

Finally, the Rwandan genocide overlapped with, and in many ways was an extension of, the Rwandan civil war (October 1990-April 1994), during which tens of thousands of Hutu civilians were killed by the then-rebel and predominantly Tutsi RPF. Often, if the RPF entered and secured a commune before Hutu extremists could arrive, Tutsi would be spared (Bangwanubusa, 2009, pp. 137-138), but massacres of Hutu would take their place (Nduwayo, 2002, pp. 9-16). As the RPF established control of the country throughout the genocide, they would also commit massacres of Hutu and occasionally Tutsi civilians (Des Forges, 1999, pp. 555-556; Kimonyo, 2019; Reyntjens, 2013; Thomson, 2018, pp. 87-94). These massacres continued once the genocide ended as the RPF consolidated its power over the state (Thomson, 2018). Currently, the RPF's former military commander, Paul Kagame, is the President of Rwanda. The RPF forbids discussion of the genocide in ways that deviate from the narrative of Hutu killers and Tutsi victims through policy instruments such as the National Unity and 
Reconciliation project. The result is a Tutsi-dominated minority government implicated in violence before, during, and since the 1994 genocide tightly controls discussion about who did what to whom in the name of national unity.

\section{Post-genocide: Rewriting the Past to Manage the Present}

In July 1994, the victorious RPF government rapidly set to work institutionalizing a new national identity category of "Rwandan" rooted in precolonial ideas about presumed ethnic and class harmony dubbed "Rwandan-ness" (Kagame, 2009; Pottier, 2002). At the heart of the campaign was the goal of eliminating "the scourge of genocide ideology" (NURC, 2000, p. 3), defined by the RPF as the racial hatred that motivated Hutu to kill their Tutsi kith and kin. By 2001, public talk about one's ethnicity had become the equivalent of supporting the genocide. ${ }^{14}$ Good citizens spoke only of being Rwandan, not of having an experience of violence based on their ethnic identity. In 2003, the revised Constitution criminalized "ethnic divisionism" and "trivializing the genocide" (article 13) by making public references to ethnicity illegal (article 33). New laws against "ethnic sectarianism" and "genocide ideology" were also passed, punishable by imprisonment and fines. Some convictions can result in 10- to 25 -year sentences (Amnesty International, 2010, p. 1), though the current iteration of the law stipulates that genocide ideology is to be punished by three to seven years imprisonment and a fine of 500,000 to 1 million Rwandan Francs. As of June 2018, Rwanda had the sixth-highest incarceration rate in the world (Wagner \& Sawyer, 2018).

\footnotetext{
${ }_{14}$ As a reminder (see pp. 5-6), we use the term "ethnicity" to refer to the Hutu and Tutsi social categories since the genocide as that is how they are currently labeled, though most often with the word "former" attached so as to avoid punishment. Thus, Thomson found in the course of her research that many Rwandans spoke of being former Hutu or former Tutsi, in an effort to not violate the new government's prohibition on using ethnic labels. Elite, urban Tutsi, however, feel generally free to proclaim their Tutsi identity as members or loyalists of the ruling RPF (for analysis, see Thomson, 2018, pp. 192-193).
} 
Central to the government's policy of dissolving ethnic boundaries is reeducating the population on the supposed unity that existed before colonialism -a time when Tutsi and Hutu lived in peaceful harmony and worked together for the good of the nation - with the purpose of constructing similar unity in the present (Purdeková, 2015; Russell \& Carter, 2019; Thomson, 2013). This is even though the current government is composed, much like the precolonial and colonial past, of Tutsi elites. Hence while seemingly inclusive and conciliatory, by romanticizing the historical past and seeking to control how ethnicity is discussed in the present, the government makes it impossible for ordinary Rwandans to openly talk about their complex experiences with violence, including experiences the government may be implicated in, in the present. This includes in the gacaca trials that the government developed to try perpetrators for their crimes.

\section{Gacaca: National Unity in the Name of Political Control}

Gacaca is the central mechanism by which the RPF government has sought to refashion individual ethnic identities into national ones by requiring Rwandans to reconcile according to their government-defined roles of killers (Hutu) and survivor-victims (Tutsi). Historically, gacaca was a process through which male elders navigated household and community disputes between neighbors or family members on small patches of grass inside traditional homesteads (inzu). Wise elders, known as inyangamugayo (persons of integrity), resolved conflicts over mundane matters including marital issues, conflicts over property and inheritance rights, as well as personal grudges. The goal was restitution in order to maintain harmony at home and social order in the community. Sanctions were likely the responsibility of the family. Resolution of the 
dispute was marked with sips of banana beer through a single straw, as a show of reconciliation. Unlike modern gacaca, the purpose was not to determine individual guilt for serious crimes nor to apply state law (for analysis, see Chakravarty, 2016; Waldorf, 2006).

Initially, after the genocide, the RPF had no intention of rolling out grassroots justice based on traditional gacaca. But quickly, the Ministry of Justice realized the magnitude of the task of holding as many genocide perpetrators as possible accountable for their crimes. Thus by 1998, the RPF had selected gacaca as the best way to ensure accountability as it would allow for mass participation at the local level in rendering justice according to the RPF's intention to involve all Rwandans in allocating guilt or innocence (Thomson, 2017). Once a week from 2004 to 2012, in jurisdictions all over the country, ordinary Rwandans were required to gather for mandatory reconciliation in front of a panel of nine inyangamugayo and follow a two-step process: The inyangamugayo would amass a dossier of evidence based on community members' input and against which the "truth," in the form of oral testimony, would be adjudicated. ${ }^{15}$ Then, witnesses would corroborate, revise, or reject the evidence presented as well as the testimony of (Hutu) perpetrators and (Tutsi) survivors. Finally, survivors would forgive the perpetrators for their crimes. In total, between 12 and 14,000 gacaca courts were established at the local level in Rwanda (Ingelaere, 2016). By the time the process came to a close in June 2012, approximately 2 million cases were heard, and $86 \%$ of people were found guilty of genocide. For the typical convict, the average prison sentence was 8.67 years, not including 2.5 years in prison awaiting sentencing (Ingelaere, 2016, p. 74). When it operated, gacaca permeated all aspects of society for ordinary Rwandans, who had to publicly confront their experiences with violence on a

15 Officials at the central prosecutor's office at MINIJUST collate and approve all dossiers before the judgment stage of gacaca begins. 
weekly basis and discuss these experiences in ways circumscribed by the government to foster national unity (Thomson, 2011) We next present our data and methods and then to analyze how ordinary Rwandans perceive gacaca as state-mandated national reconciliation in the name of Rwandan-ness.

\section{DATA AND METHODS}

This chapter draws on ethnographic research carried out over a cumulative nine-month period in 2006 with 37 ordinary Rwandans resident in the south of the country (Thomson) and in 2009 with 10 ex-combatants in a Demobilization and Reintegration center in the northwest (Luft). ${ }^{16}$ Of the 37 Rwandans whose perspectives we analyze in this study, three identified as Twa, 20 as Hutu, and 14 as Tutsi. All lived through the 1994 genocide. Consequently, the sample is representative of Rwandans at the lowest rungs of society, as it is composed of individuals who live on less than US\$1/day, accounting for approximately $66 \%$ of the country's population (Howe \& McKay, 2007).

In addition, Thomson conducted life history interviews with a cross-section of elite and ordinary Rwandans, living in all corners of the country, from 2013 to 2016 . A team of four Rwandan researchers undertook these interviews over a 30-month period, in Kinyarwanda and translating them into English, on themes of everyday life since the 1994 genocide. Few prompts

\footnotetext{
16 Specific place or community names are intentionally avoided to respect the confidentiality and anonymity protocols set out in the research design, and to protect the safety of Rwandan assistants and translators from possible government backlash. Additionally, names used throughout the chapter are pseudonyms. Approval from the Research Ethics Board (Human Subjects) at Dalhousie University to conduct the research in 2006 was received in April that same year (project \# 2005-1257). See Thomson (2010) for specific details of the research methodology, which resulted in her 2013 book. Some of her 2013-2016 interview data appear in her 2018 book.
} 
were provided; instead, interviewers spoke to individuals about their daily stresses and strains, and the role of local government officials in their lives.

Furthermore, both Luft and Thomson conducted semi-structured interviews with Rwandan government officials, from members of the Senate and the Office of the President down to local gacaca judges that resulted in 79 hours of recorded material as well as a cache of primary documents related to the National Unity and Reconciliation project, including mandatory reeducation curricula. Approximately 400 others from across the country were also consulted through participant observation by Thomson - meaning spontaneous, casual conversation in the course of everyday life - on the themes of national unity, justice, peace, and reconciliation. Luft participated in and observed memorial ceremonies throughout the country on the anniversaries of particular massacres.

Finally, the research is informed by Thomson's participant observation of 31 individual gacaca trials in 12 jurisdictions across central, southern, and western Rwanda, in which 29 of 37 informants were present. It is further bolstered by observation of seven gacaca trials in September 2006, which provided behind-the-scenes insight into the power relationships between representatives of the Ministry of Justice, local government officials, military and police officers, and gacaca judges before and after the proceedings. Luft's participant observation of a classroom where ex-combatants were being reeducated in the name of national unity likewise informs this analysis.

Lastly, the locally grounded and contextualized narratives provided by the individuals we consulted reflect a methodology that allowed them to express themselves in their own words and as "knowers" of their own life stories. This approach to collecting data also leaves space for 
analysis of the extent to which their narratives do not match the Rwandan government's rhetoric about gacaca's utility in unifying the nation. We privilege the locally situated knowledge that Rwandans possess by employing narrative tools that uncover, rather than pre-suppose, individuals' emotions when discussing their motivations and behaviors.

\section{RESENTMENT TOWARD RECONCILIATION: WHY THE NEW "RWANDAN" NATIONAL IDENTITY IS FAILING TO TAKE HOLD}

Our analysis of ordinary Rwandans' perceptions of gacaca reveals that they resent the government's postgenocide policy of national unity and reconciliation because it does not square with their experiences during the genocide nor the civil war that preceded it (1990-1994), it activates painful memories while reminding them of the government's control, and it detracts from their much more pressing concerns of poverty and economic inequality, which they partially blame on the government's prioritizing superficial unity rather than meaningful change. This resentment highlights the ongoing salience of ethnic categories in everyday life, as well as the government's dominance from above, which our respondents experience as significant precisely because their forced participation in gacaca rarely accords with their lived experiences. Since ordinary Rwandans feel unable to sincerely express themselves and to describe their experiences with violence and their consequences, participation in mandatory national unity and reconciliation projects paradoxically serves as a constant reminder that state-run reconciliation is superficial. In turn, the "structuring structure," to reference Bourdieu $(1989$, p. 18) is everpresent in the minds of ordinary Rwandans, impeding the government's goals of remaking subjectivities and naturalizing its rule in turn. 


\section{A Complex Binary}

Ordinary Rwandans we consulted hold firm to their Hutu and Tutsi identities because they informed how they experienced the civil war and genocide. No one who lived in Rwanda in 1994 escaped the horrors of genocide. Tutsi, in particular, suffered tremendously. Yet Hutu, too, have been traumatized by the genocide - by the horrors of seeing family, peers, and neighbors become murderers, of coping with having become a murderer oneself, and of losing beloved family members and friends who were Tutsi or Hutu resisters with no opportunity to properly mourn these deaths or have their own identities as survivors officially recognized. The Hutu/ Tutsi categories have profoundly shaped Rwandans' relationships to politics throughout their history, as analyzed above, but they became more acute and relevant for life and death outcomes than ever before in 1994. Importantly, as mentioned above, this does not mean that only Hutu killed only Tutsi or that Hutu killed Tutsi because they believed elite identity machinations. Rather, the Hutu/Tutsi binary shaped how Rwandans made decisions during the genocide given extremists' pressures on all Hutu to participate in the murder of all Tutsi.

Consider the following quote by Tharcisse, a Hutu who was married to a Tutsi woman before the genocide and who participated in the violence but also tried to save his wife, three children, mother-in-law, and brothers-in-law:

For me, the truth is hard for [local officials] to accept. I killed some, but I protected others. I was even married to a Tutsi so this idea that all Hutu killed because we hated Tutsi is a bad one that the government likes us to talk about. She died, and so did three of our kids. But I tried to save her, and even her mother and her brothers. Some of her family survived because I told them when the interahamwe [militia] were coming and I pointed out good places to hide. So the truth of what I am supposed to say [before gacaca] is different than what actually happened. This is justice for Hutu like me. 
Like many Rwandans, Tharcisse's experiences during the genocide do not align neatly with the forced overlap, mandated by the government, between the behavioral categories of perpetrator and victim with the social categories of Hutu and Tutsi (Luft, 2015, pp. 148-9). Instead, throughout the genocide, ordinary Rwandans we consulted frequently made difficult choices about whom to kill and whom to save, sometimes even participating in violence in order to save those with whom they were close (Luft, 2015, pp. 163-4; Thomson, 2018, pp. 28-9). Yet there is no room in gacaca to speak about these experiences openly given that justice in Rwanda is scripted: (Hutu) perpetrators are required to tell the truth about what they did - which is limited to acts of violence - while (Tutsi) survivors must forgive perpetrators, also required by the law. This becomes further complicated when Hutu survivors, often women whose Tutsi husbands were killed during the genocide, are likewise forced to participate in gacaca and adhere to the government's strict narrative. Aurelia explains:

I was a Hutu. My husband was Tutsi. He died trying to save me and the children. We all survived but one. I was targeted not because my kids are Tutsi because their father is Tutsi. I mean how can I not be considered a "survivor"? The authorities say it is because I am a Hutu. But [male members of my family] are gone; who cares for me? And I have these kids to feed, to send to school.

Like Tharcisse above, Aurelia's statement demonstrates how experiences during the genocide were more complicated than the simple Hutu 5 perpetrator/Tutsi 5 victim classification scheme suggests. Particularly given the high rates of intermarriage and integration among ordinary Rwandans before the genocide, many Hutu privately identify as survivors, but they cannot openly express these sentiments for fear of retribution. The result is that obligatory participation in gacaca and forced adherence to the government's narrative serves as a persistent reminder of 
the state's explicit domination and that ordinary Rwandans must conceal their "true" identities in favor of a superficial and inescapable reconciliation practice mandated by the government.

This is especially upsetting to people like Thomas, who feel betrayed by the government's forced national unity while the government itself is comprised of elite Tutsi RPF who were responsible for massacres of Hutu and some Tutsi before, during, and after the genocide. Thomas explains how, during the genocide:

Killing was the law. ${ }^{17}$ We had to kill or suffer ourselves! Hutu killed Tutsi but Tutsi also killed us. There was a civil war, you see! We knew our enemy was Tutsi. I killed. Yes, but I was also following Interahamwe [militia] orders. It was an extreme time and some of us did extreme things. ${ }^{18}$ I admit to that. But we cannot forget that the RPF are foreigners and they killed our president! ${ }^{19}$ They came from outside to oppress Hutu. That cannot be overlooked. Tutsi leaders have always oppressed Hutu like me. This issue of ethnic groups cannot be swept away. Now the government is made up of extremist Tutsi who say ethnicity doesn't matter.... So, we Hutu suffer as killers, rotting in prison while Tutsi who killed are outside, living free.

Thomas, who confessed to killing in the genocide and was jailed as a result of a 2010 gacaca trial, expresses outrage in his statement that precisely what Hutu were told to fear has come to pass: Rwanda is currently controlled by an elite Tutsi minority, much like before and during colonialism, while tens of thousands of Hutu have been oppressed through mass incarceration.

\footnotetext{
${ }^{17}$ As mentioned above, Straus (2006, pp. 227-239) corroborates Thomas' perception that Hutu perpetrators killed Tutsi because it was the law of the land, citing the authority of the state, a culture of obedience, and a broader climate of insecurity.

18 On the climate of fear and uncertainty from 1990 to 1994, cited by Thomas as "extreme things," see Thomson (2018, pp. 17-32). To compare anti-Tutsi rhetoric in the 1950s and 1990s, see C. Newbury (1998, pp. 14-18).

19 Importantly, responsibility for President Habyarimana's assassination remains unclear to this day. According to the latest data, responsibility lies with the Rwandan Patriotic Front and current Rwandan President Paul Kagame (see for example, http:// https://www.theglobeandmail.com/world/article-new-information-supports-claimskagameforces- were-involved-in/). According to President Kagame, however, the president's plane was shot down by Hutu extremists who were a part of his inner circle and who intended to eliminate and intimidate moderates in the government, including the president himself (Lemarchand, 2018). At the start of the genocide, Habyarimana's supporters blamed the assassination on the RPF and used the opportunity provided by the crisis of his assassination to mobilize civilians into violence (Luft, 2019b, pp. 15-17).
} 
The National Unity and Reconciliation project, however, by making it illegal to discuss the true complexities of Rwanda's past violence, allows Tutsi RPF to avoid account-ability for these actions. The ordinary Rwandans we consulted in the course of our research thus resist the state's attempts at constructing a new national identity because abandoning their Hutu or Tutsi identities in the wake of such severe violence that was, and in many ways, remains, organized along these lines feels impossible and insulting of their true experiences, which the national unity project forbids them to discuss. Rwandans feel a need to rely on these categories to explain what happened to them, even when what happened is not as neat as the state's imposed narrative of Hutu killers and Tutsi victims.

\section{The Heavy Hand of the State}

Crucially, it is not just Hutu who perceive gacaca as requiring superficial recon-ciliation; Tutsi, as well, feel as if their social scripts are forced. In particular, they begrudge the government for coercing them into "survivor" roles and their need to forgive in the name of national unity rather than allowing them to live peacefully and privately without constant government intrusion concerning their memories of the genocide. Witness Jeanne, a Tutsi widow whose Hutu husband died of disease in 1996 after they fled to a refugee camp in Democratic Republic of Congo following the genocide. ${ }^{20}$ Jeanne evokes the pain caused by the government's requirement that Tutsi as survivors must forgive Hutu perpetrators at gacaca:

\footnotetext{
20 In July 1994, when it was clear that the RPF rebels would win the war, members of the Hutu extremist government forced Rwandans into neighboring Democratic Republic of Congo (then Zaire). The extremists used genocidal rhetoric to ensure a mass exodus, explaining that the Tutsi-led RPF would seek reprisal, something that many ordinary Rwandans feared. As a result, more than a million Rwandans, Hutu and Tutsi alike, poured into eastern DRC. By September 1994, an estimated 1 million Rwandans lived in UNHCR-operated refugee camps. The RPF forcibly returned many of these refugees to Rwanda in 1998 (Thomson, 2018, pp. 79-83).
} 
I had a visit from [local government official] who told me that [the accused] had made a statement that he killed my family. I was amazed. It was like God struck me down. How could this be? I was very nervous but also very excited. I wanted to know what happened to my family but not really. I mean I am alone now. I was raped and I know that I will not remarry. I am too old. And by this time even barren. Who would marry me?! So, I know that I am alone and I try my best to stay silent so that I can live the rest of my days in peace. I just want peace. I am a member of [survivor's organization] and they give me some small money and I still have my land. So I was as happy as I could be after the genocide.

Now I have to relive all of that bad memory. I know how my people were killed. I was there! I was younger then and was able to run away you know. I just ran into the [banana] grove. Other women talk about how they made efforts to protect their children. Me? I just ran. I guess that means I didn't love my children as much as those other women. I just didn't want to confront the man. I would like to have the remains of my people buried at home, but I would rather stay out of the way of gacaca if I could.

Of course, I could not say no because it is my duty to forgive. So he [the accused] stood up and I recognized him as the husband of my sister! It was not the man I thought it was at all. No! I just broke down then. I just stopped moving and I don't think I have moved since. This is why I am not afraid to speak to you because my life is over. I don't know why they call us "survivors."

How can I get peace like this? Really. I wish I never learned the "truth" as the gacaca says it is. I had some peace, as much peace as an old woman like me can have and now I am supposed to live with this news? I wish I never was told to go to gacaca that day. I hardly sleep or eat since...

Jeanne's testimony shows how the required discourse at gacaca of justice, reconciliation, and national unity masks the profound social divisions that gacaca in practice silently reinforces and even exacerbates. Her words also document the extent to which she, and others like her, resent the presence of the government in daily life.

As ordinary Rwandans strive to move forward - to preserve their memories of loved ones while also struggling with their own experiences during the genocide -they are constantly reminded of their past traumas and even directed to recall them in specific ways by the state. 
Gacaca brings these memories and the politics surrounding them to the surface, which hurts Rwandans and even angers them as they simply wish to be left in peace. Hence, Jeanne's words are mirrored by Joseph M., who likewise expresses pain and resentment at having to follow the government's narrative in the name of "Rwandan-ness." He says:

I know I am a former Tutsi. How can I not? I ran and hid because of being Tutsi. Now I have to forget that in the name of justice and peace? Justice is just a political game that local officials take responsibility for. Reconciliation is not an administrative matter; it is an affair of the heart, of accepting wrong and then forgiving the ones who harmed you.

Finally, though not about gacaca, Janvier describes his frustration at having to participate in "mourning week"-another mandated practice of national unity and reconciliation - in ways circumscribed by the government:

Mourning week is a joke. How stupid does this government think we [Tutsi] survivors are? We [Tutsi] talk about the ways this government disrespects our lives. I mean, we were targeted because we were Tutsi; now we have to forget about that in the name of national unity and reconciliation. Me, I cannot. Tutsi is what I am. So the officials make speeches, and we have to mourn in "official" ways. This means nothing. Many of my people are really dead; many around me are alive, but they act like they are dead. Seriously, this idea that I am a survivor is too much to bear.

For Tutsi like Jeanne, Joseph M., and Janvier, the national identity of "Rwandan-ness" is far removed from their everyday lives and how they would like to process their grief in their own ways and with their own recollections of the violence. As a result, the requirement that they express forgiveness in gacaca and play their part in unifying the country only serves to illuminate that the Hutu and Tutsi categories are still salient and their suppression is to serve a 
commanding force. Alice, a Tutsi widow who lost her husband and two of her five children during the genocide in an attempt to escape to DRC, is succinct:

Don't talk to me about gacaca! It is something that this new government has created to maintain its own power. It doesn't care about survivors like me. They [local officials] have to make reconciliation appear and they do it by forcing us to forgive and forget as a way to get unified. Forgiving and forgetting is a joke when justice has to be done a certain way. But for me, forgiving is impossible. I lost my family and am more poor now than ever. And the government says they are for Rwandans? Really, they are for themselves and we [peasants] are left to pick up the pieces. This is the justice of gacaca in Rwanda.

Like others, Alice's testimony highlights how ordinary Rwandans go along with the RPF's dictates while privately holding firm to their personal memories of the genocide. Beatrice also discusses the performative qualities of unity and reconciliation practiced during gacaca, which even Rwandans who were not alive yet during the genocide must participate in:

Making Hutu apologize [at gacaca] for things their ethnic brothers and sisters may have done is absurd because it doesn't matter what actually happened. You apologize to get perks like bursaries to study or even health cards. You forgive to keep these benefits....It's simple: young Hutu must apologize, even if we were not even alive in 1994! I apologized to keep studying and to avoid conflict. A girl I know refused to apologize at the ceremony on campus. She said "no" several times. Finally, the police came to take her away. She is no longer in residence, and I heard she fled to Uganda to avoid getting arrested. This is so normal. You do what you are told or you suffer the consequences.

Rwandans are pressured to practice national unity and reconciliation in particular ways or risk grave harm. In turn, the regular retelling of the state's genocide narrative reminds them that these practices are so the government can exert power. Hence, while they act in line with these requirements, their engagement in them is not reforming their self-perceptions about their social 
identities. In fact, it is doing the opposite and reinforcing them instead, while simultaneously rendering the government illegitimate along with its nation-making project.

\section{Participation versus Livelihoods}

Last but not least, though building on Alice's statement above, our analysis finds that ordinary

Rwandans are resentful of the government's forced national unity and reconciliation project

because it interferes with their abilities to pursue their livelihoods. In particular, participation in gacaca requires ordinary Rwandans to give up precious time that could otherwise be spent harvesting crops and precious resources such as funds needed to pay for children's school uniforms, as they must use what little money they have to travel to and from trials instead. As a result, an issue much more pressing for them than reconciliation is survival, and without the economic resources they need to get by, a genuine Rwandan national identity cannot take hold.

Consider Béatha's situation as a Hutu widow with nine children, seven of whom she adopted as orphans of the genocide:

[The local government official] came and he asked me why I didn't attend the gacaca. I told him because my son is sick, and I stayed home with him. He wrote something in his book and said, "Next time you have to come. I don't care the reason." So I got scared because my son wasn't sick at all! It was that I had no money to spare for transport but I didn't tell him because I know that is no excuse. ${ }^{21}$ The radio says we have a responsibility to participate so we can forgive those who killed and live in unity and peace. But I didn't see anything so what can I say? I heard people getting killed but I was in hiding. I mean, I hid when [the killers] came. Who didn't? We all hid [during the genocide]. I don't know who saw what, but I say that I saw nothing. I heard the official tell someone whose name I know to kill but I didn't see it. If he killed, I don't know. So why go

21 Transport from some outlying communities to the local government office costs as much as $400 \mathrm{RWF}$ (\$0.44 USD) each way, an astronomical sum for subsistence farmers who live, on average, on less than one USD per day. As gacaca was a weekly event, it can all but eliminate the monthly household income for the participation of one individual. 
if I have nothing to say and if I have no money? How do I get money to go? I am not a survivor so am not a member of an association; money for school uniforms is now due. Now I have a big headache because he knows I did not go and gacaca is again next week. Next week! And now my neighbors know [the Cell coordinator] has come so I have to go.

Béatha's testimony reveals how difficult it is for ordinary Rwandans to resist participation in gacaca despite the fact that such participation might cause them to incur significant financial strain. In addition to government-mandated requirements that civilians participate, neighbors also feel responsible for holding other neighbors accountable lest they get struck with punishment by the state as well.22 Thomson (2013, p. 168) explains:

Official state-based sanctions (fines, imprisonment) for non-participation matter, but so do the watchful eyes of friends, neighbors, and, in some instances, family in ensuring the full participation of the population at gacaca.

This self- and other-monitoring behavior further impedes true reconciliation as it compels

Rwandans to be suspicious of one another as a result of the state's dictates.

Yet other respondents express resentment at how being a "good citizen" and participating in national unity and reconciliation projects exacerbates their poverty, resulting in frustration. Ésperance, a Tutsi who is the sole surviving member of her family, explains:

Being "good" and "productive" often means I go to sleep hungry. At least I am mostly alone. But for some [neighbors] it is too much to bear. They struggle even more than me, and I struggle a lot. At least I benefit from membership [in a local survivors' group]. There I can join with others and we can strategize how to be "good." For others [nonmembers], their chances are few. I tell you, if they gave food at gacaca, everyone would go!

\footnotetext{
22 The RPF has an impressive reach into the everyday lives of all Rwandans. This reach is a product of "clear hierarchies and an intricate organization" that appoints government officials to positions with overlapping administrative roles (Purdekov'a, 2011, p. 481). Official restructuring in 2006 decentralized state bureaucracy under the guise of better grassroots service delivery. Units of governance are divided into six levels: five provinces, including Kigali City, 30 districts, 416 sectors, 2,146 cells, 14,774 villages and umukuru (village committees). As of this writing, local government officials represent fully half the government's payroll (Chemouni, 2016, p. 246).
} 
Later, Ésperance adds, "reconciliation is for people who can afford to eat." A woman who identifies as "former Hutu" and who was just eight years old during the genocide, Likewise, Olive, complains:

I am an orphan of the genocide, so I know about pain. But these rules [of Rwandan-ness]! How can I afford to eat, to send everyone to school and just make sure we survive? It's impossible because I have no adult support, and when I go to my local official to seek help, he gives me a fine for breaking some rule or another. I am also not a real survivor [as a former Hutu] so getting support is hard.

Finally, Jeanne, who earlier described the pain of being forced to forgive her husband's sister, also expressed resentment at how gacaca doesn't provide any tangible benefits: "Participating comes with nothing for nothing. Maybe I would accept more easily if I could get some kind of [monetary] settlement." Together, these narratives demonstrate how, for ordinary Rwandans, the need to participate in gacaca is often at odds with their needs for basic survival. Jeanne adds angrily,

Everything in the country is political. I am hungry. I have seen people die during war and starve during so-called times of peace. If you can't feed your family, then your thoughts are about survival, not about much else. Of course, we need peace. But there can be no peace in the heart if there is no peace in the stomach.

The Rwandan government ties participation in national unity and reconciliation to what it means to be a good Rwandan, but without the resources to participate while simultaneously feeding themselves and taking care of their families, respondents feel resentful of reconciliation from above.

In fact, this resentment even extends to ordinary Rwandans with slight positions of authority in gacaca as they, too, must participate according to the government's demands at cost 
to themselves and at personal risk of harm for noncompliance, which they fear can extend to their families. ${ }^{23}$ Didier, a Tutsi who survived by hiding in a chicken coop owned by a Hutu friend that killed others during the genocide, and who was appointed as a judge for gacaca, also expresses frustration at his need to perform in line with the government's orders to provide for his family. Didier likewise struggles with his requirements, as a judge, to dictate what he feels are false outcomes in order to align with official national unity and reconciliation policy:

It is a most difficult thing to be a judge. And no one understands. There is no one I can share my difficulties with.... And because I have a family, I have responsibilities to them. My wife even asked how I could let my family starve when it was time to harvest. But I couldn't do that work because it [being a judge] takes at least two days a week, sometimes more....If I don't undertake my duties as a judge, I can get into serious problems with [the appointed local government official that he reports to]. And I can also get into serious problems with other survivors.

Last year, we acquitted a Hutu who was accused. We didn't have enough evidence or information to do anything but let him go. So we did. I truly before God did not think he was guilty. And no one spoke up about his role. It didn't sound like he did anything. And he was sorry. He fell on the ground [in front of his accuser] and said, "I'm sorry, I'm sorry, I'm sorry." The survivor accepted, and we all felt happy about the power of gacaca at that moment. I was proud to be a judge, you know, really proud. Then, the day after, the IBUKA lady requested to see all of us judges. I was in my field trying to feed my family the few beans we had left. She said that the survivors around me [in his community] were so angry with us. Then she raged against me, and I felt like I did the best I could in deciding how the accused was telling his truth. I said I was sorry but I don't think it [the evidence against the accused] was enough. I fear now that I am going to be denounced because I was told [by the other judges] that she [the IBUKA representative] is very powerful with many connections in Kigali.... What if something happens to me? Who will take care of my family?

\footnotetext{
${ }^{23}$ For a lengthier discussion of the complex experiences of gacaca judges in Rwanda, see Brehm, Frizzell, Uggen, and Gertz (2021), who highlight the mixed feelings of pride, confidence, stress, and trauma that former gacaca judges feel as a result of their activities.
} 
As with the others whose testimonies are considered here, Didier feels coerced into participation and especially coerced to classify Hutu as killers due to his poverty. He is extremely aware that how he participates in gacaca is circumscribed by the state. If he resists its orders, Didier can harm himself and his family. Ordinary Rwandans participate in gacaca because they feel they have no choice, but such mandatory participation fosters resentment at having to prioritize superficial reconciliation when their real struggles are economic. The result is that the reconciliation charade is constantly made clear: unity is for the government, exerting force from above, but true "Rwandan-ness" is not, in fact, taking hold, precisely because it is not in the interests of those who are its targets, who struggle to rebuild their lives while living in fear of the state.

\section{DISCUSSION}

This chapter examines how ordinary Rwandans perceive the state's attempts since the 1994 genocide to reshape their subjectivities from primarily identifying with the Hutu and Tutsi categories that have long been salient for politics to identifying with the new, national category of "Rwandan" instead. We analyze 37 interviews with Rwandans about gacaca, a system of grassroots justice that comprises a key part of the state's National Unity and Reconciliation program, as well as ethnographic observations from nine months of fieldwork alongside a close reading of Rwandan history, and we find that the state is failing to naturalize its new national category for three reasons.

First, Rwandans had complex experiences during the genocide that do not accord with the government's narrative of all Hutu as perpetrators and all Tutsi as victims, but gacaca requires 
that they forge national unity on the basis of this false binary. This erasure of their lived experiences, where some Hutu were rescuers or victims, others lost Tutsi spouses and children, and the majority did not participate at all, breeds anger toward the government, particularly given its own role in perpetrating violence during this time-period, which Rwandans are forbidden to discuss. This in turn reinforces the salience of their Hutu and Tutsi identity categories as they are forever aware that the state's nationalizing project seeks to negate the true complexity of their experiences. Rwandan's Hutu and Tutsi identities remain meaningful to them precisely because their experiences tied to them are too important to dissolve easily into the state's nationalizing project. Hence, the state's imposition of a new national category is failing because it erases Rwandans' lived experiences and these experiences are important given the history of the genocide.

Second, because ordinary Rwandans are unable to openly discuss their true experiences with violence, they resent the state and are persistently aware of its heavy-handedness in trying to change how they remember the past. In fact, their forced participation in gacaca and other National Unity and Reconciliation even exacerbates ethnicity's salience by forever placing the past in the present, keeping painful memories vivid and alive while constraining how they can be discussed. As a result, rather than naturalizing the new national category to become a taken-forgranted feature of the sociopolitical landscape, Rwandans instead feel the weight of the state and its pressures to nationalize constantly. This in turn fosters anger as it leads Rwandans to interpret the government's efforts at reshaping their subjectivities as a top-down project to maintain power. They comply with gacaca to avoid punishment, but privately, they believe the state's national unity project is a ruse. 
Third, the constant pressure Rwandans feel to nationalize by reconciling according to the government's dictates breeds resentment because the practices by which they must do so interfere with their much more pressing concerns of striving to achieve economic security. Participating in gacaca costs time and money that ordinary Rwandans do not have. This leads them to feel frustrated with how the government's national unity project exacerbates their existing struggles. Since there is no economic benefit to gacaca, only potential harm, Rwandans comply with the practice of national unity, but they are aware at all times that this is to placate the state - that Rwandan-ness is a ruse they are coerced into enacting, even while privately, they resist it.

These findings demonstrate the significance of studying state categorization and classification projects from below. Theories of symbolic power founded largely on top-down analyses propose that states succeed when they co-opt traditional practices (Loveman, 2007, pp. 1662-64), when these practices require civilians to think using the state's categories(Anderson, 1991; Bailey, 2008; Bailey \& Fialho, 2018; Francis-Tan \& Tannuri-Pianto, 2015; Goldberg, 1997, pp. 27-58; Kertzer \& Arel, 2002; Lieberman \& Singh, 2012, 2017; Loveman, 2014; Star \& Lampland, 2009; Starr, 1992), and when new categorical distinctions are tied to privilege and punishment (Bailey et al., 2018; Bailey \& Fialho, 2018; Brubaker, 1996; Cornell \& Hartmann, 1998; Davis, 1991; Jenkins, 1997; Marx, 1997; Mora, 2014; Nagel, 1995). These same theories propose that when states fail to naturalize new social categories, it is because they lack the capacity to engage in these practices, making them also unable to transform social relations. Yet each of these features characterizes gacaca in Rwanda, which is a strong state with the capacity to practically carry out its nationalizing project as evidenced by widespread compliance with 
gacaca and punishment for those who resist. A top-down analysis privileging the state's perspective in Rwanda would therefore anticipate a positive outcome of civilian subjective transformation. And indeed, the mere existence of gacaca is often pointed to as evidence of national reconciliation in Rwanda in both scholarly research and journalistic reports (e.g., Clark, 2010; Kinzer, 2007). Yet our bottom-up analysis finds the opposite - that Rwandans are holding firm to their Hutu and Tutsi identities and are not foregoing them in favor of "Rwandan-ness"providing us with leverage to understand the circumstances under which states are or are not likely to succeed in remaking individual subjectivities. Below, we detail several lessons from our findings that point to new directions for future research.

Concerning our first finding, future research ought to consider how different forms of violence and warfare influence the state's ability to make or unmake civilian subjectivities. Many theories of state symbolic power indirectly relate to wartime practices such as conscription and taxation, identified by Tilly (1990) as central to the nation-state-making process, because they require high state capacity and widespread civilian compliance. Genocide also requires high state capacity and civilian compliance but has the opposite outcome: instead of integrating civilians into the nation by tying them to the state, the state targets its own civilians in genocide because of their perceived or actual affiliation with a collectivity the state classifies as threatening (Luft, 2019b, p. 4). This is important. As we show in this chapter, whether or not civilians believe the state's narrative and whether or not they act accordingly with its behavioral expectations, genocide increases the salience of social categories since how civilians identify and are identified by others becomes a matter of life or death. This in turn has boundary-strengthening consequences (Luft, 2015, p. 164) - the opposite from how social theorists typically understand the 
relationship between war and nation. Accordingly, while one implication of our study is that genocide makes the social categories central to those conflicts particularly sticky, future work would benefit from a comparison of the social boundary making and unmaking consequences of conventional war versus genocide and other comparable instances of mass violence.

Our second finding suggests it is not simply genocide but authoritarianism after genocide that generates resistance to the state's re-categorization project. This challenges the assumption in much literature on symbolic power that if a state project fails, it is due to a lack of capacity. In fact, it even suggests the opposite: that in cases where the state has high capacity to implement its administrative projects, as well as high capacity to punish citizens for noncompliance, civilians have increased awareness of the state's intentions, which can motivate resistance, albeit discreetly. This finding mirrors work on resistance to authoritarianism by Wedeen (1999) and totalitarianism by Kotkin (1995),whichfinds that despite aggressive top-down efforts to control how civilians think and live, people remain able to devise creative ways of circumventing these projects. Future research ought to consider how different forms of governance influence the likelihood of resistance to new state legibility practices. It could be that the more obvious and aggressive a state is in its efforts to implement new modes of vision and division, the more likely people are to develop creative ways of resisting them, even while overtly participating in the state's administrative practices.

Our third finding emphasizes the importance of attending to whether or not the state's categories and the practices they are tied to are in civilians' interests. Research by Mora (2014) and Paschel (2016) demonstrate the important role of civilian-led interest groups in convincing the state to adopt new categorization practices, while Rodríguez-Muñiz $(2017,2021)$ shows how 
state actors can recruit representatives of targeted populations to convince those same populations to adopt new social categories as their own. Emigh et al. (2016, 2019, n.d.), in a series of studies, argue that states succeed in gathering and producing knowledge only insofar as their projects align with social interests and resonate with existing categories. Our chapter provides evidence from the perspectives of civilians themselves that their interests matter - that even when the state has the capacity to compel civilian compliance with its top-down practices, ordinary people may resist its imposition of new social categories if they do not feel they serve their needs. Further, they may comply with the state's practices that are supposed to produce a reshaping of their subjectivities but still resist this latter trans-formation. Compliance and conviction are distinct, and a bottom-up approach to studying state symbolic power and legibility allows researchers to probe when they do or do not align.

\section{CONCLUSION}

In Rwanda's past, precolonial, colonial, and postcolonial elites have all sought to manipulate the meanings of the Hutu and Tutsi categories to serve their political interests. But it is not clear that ordinary Rwandans have always ideologically succumbed to these projects. In fact, as our review shows here, ordinary Rwandans frequently resisted these projects during the genocide, when the meanings attributed to the Hutu and Tutsi categories mattered most.

Moreover, that regional differences mattered more for politics than race in the 1970 s1990s shows there was once a potential for alternative cleavages to drive Rwandan politics and the Hutu/Tutsi binary was not always the master political cleavage. This suggests that colonialism's impact is not fixed. Rather, he significance of race and other categories for politics 
is continuously made and remade as race is tied, whether overtly as in the past or covertly as in the present, to structural inequalities.

In contemporary Rwanda, the government is led by ethnic Tutsi tied to Kagame's RPF. Access to politics, education, land, money, and, of course, the law hinges on loyalty to the party, compliance with its dictates, and alignment with its false narrative of the genocide. Rwandans who try to step outside the proscribed frames of National Unity and Reconciliation are met with quick and relentless punishment: imprisonment without charge, disappearance, intimidation, even death (Reyntjens, 2013, pp.90-93; Thomson, 2018, p. 197). This means that perpetrators (read as Hutu) and survivors (read as Tutsi) have been cast into essentialist categories of killer and victim with no room for variation despite significant behavioral variation during the genocide (Fujii, 2009; Luft, 2015). Thus despite the illegality of public discourse using the words "Hutu" and "Tutsi" lest one be accused of ethnic divisionism, in practice, what it means to be Hutu or Tutsi is once again being tied to ideas about inherent difference by those with political authority with consequences for Rwandans who seek to challenge these classifi-cations. All this is in addition to the lack of accountability for the RPF's own crimes under then-military commander Paul Kagame during the civil war, as well as its ongoing perpetration of violence both directly and by proxy against Hutu rebels and refugees in the Democratic Republic of Congo (Loyle \& Davenport, 2015, p. 140). If President Kagame truly wished to help Rwanda overcome its violent past, he could therefore start with some mechanism of finding out what actually happened during the genocide and civil war and introducing justice on an evidencebased procedure rather than race as a synonym for behavior. Our analysis of Rwandans' resistance to state symbolic power makes this clear. 
Acknowledgments: We are deeply grateful to Rebecca Emigh, Jared McBride, katrina quisumbing king, Alexandre White, Julian Go, and to the anonymous reviewers for their feedback on previous drafts. 


\section{REFERENCES}

Amnesty International. (2010). Country report - Rwanda. 28 May. Retrieved from https://www. refworld.org/docid/4c03a80564.html. Accessed on May 26, 2019.

Anderson, B. (1991). Imagined communities: Reflections on the origin and spread of nationalism (Rev. ed.). London: Verso.

Bailey, S. R. (2008). Unmixing for race making in Brazil. American Journal of Sociology, 114, 577-614. Bailey, S. R., \& Fialho, F. M. (2018). Shifting racial subjectivities and ideologies in Brazil. Socius, 4, 1-12.

Bailey, S. R., Fialho, F. M., \& Loveman, M. (2018). How states make race: New evidence from Brazil. Sociological Science, 5, 722-751.

Bangwanubusa, T. (2009). Understanding the polarization of responses to genocidal violence in Rwanda. Retrieved from https://gupea.ub.gu.se/handle/2077/21470. Accessed on January 26, 2014.

Bourdieu, P. (1989). Social space and symbolic power. Sociological Theory, 7(1), 14-25.

Bourdieu, P. (1991). Language and symbolic power. Cambridge, MA: Harvard University Press.

Bourdieu, P. (1999). Rethinking the state: Genesis and structure of the bureaucratic field (L. J. D. Wacquant \& S. Farage (Trans.)). In S. George (Ed.), State/culture: State formation after the cultural turn. Ithaca, NY: Cornell University Press.

Bourdieu, P. (2000). Pascalian meditations (R. Nice (Trans.)). Stanford, CA: Stanford University Press.

Brehm, H. B., Frizzell, L. C., Uggen, C., \& Gertz, E. (2021, April 5). Consequences of judging in transitional justice courts. The British Journal of Criminology. Advance access publication.

Brubaker, R. (1996). Nationalism reframed: Nationhood and the national question in the New Europe. Cambridge: Cambridge University Press.

Brubaker, R. (2002). Ethnicity without groups. Archives europ'eennes de sociologie, 43(2), 163-189.

Brubaker, R. (2013). Categories of analysis and categories of practice: A note on the study of Muslims in European countries of immigration. Ethnic and Racial Studies, 36(1), 1-8. 
Burnet, J. E. (2012). Sexual violence, female agencies, and sexual consent: Complexities of sexual violence in the 1994 Rwandan genocide. African Studies Review, 55(2), 97-118.

Carroll, P. (2006). Science, culture, and modern state formation. Berkeley, CA and Los Angeles, CA: University of California Press.

Chakravarty, A. (2016). Investing in authoritarian rule: Punishment and patronage in Rwanda's Gacaca courts for genocide crimes. Cambridge: Cambridge University Press.

Chemouni, B. (2016). Explaining the design of the Rwandan decentralization: Elite vulnerability and the territorial repartition of power. Journal of Eastern Africa Studies, 8(2), 246-252.

Clark, P. (2010). The Gacaca courts and post-genocide justice and reconciliation in Rwanda: Justice without lawyers. Cambridge: Cambridge University Press.

Cohn, B. (1987). The census, social structure and objectification in South Asia. In B. Cohn (Ed.), An anthropologist among the historians and other essays (pp. 224-254). New Delhi: Oxford University Press.

Cornell, S., \& Hartmann, D. (1988). Mapping the terrain: Definitions. In S.Cornell \& D.Hartmann (Eds.), Ethnicity and race: Making identities in a changing world (pp. 15-37). Thousand Oaks, CA: Pine Forge.

Curtis, B. (2001). The politics of population: State formation, statistics and the census of Canada, 1840-1975. Toronto, ON: University of Toronto Press.

Davis, F. J. (1991). Who is black? One nation'sdefinition. University Park, PA: Pennsylvania State University Press.

Des Forges, A. (1995). The ideology of genocide. Issue, 23(2), 44-47.

Des Forges, A. (1999). Leave none to tell the story: Genocide in Rwanda. New York, NY: Human Rights Watch.

Desrosiers, M.-E. (2014). Rethinking political rhetoric and authority during Rwanda's first and second republics. Africa, 84(2), 199-225.

Desrosiers, M.-E. (2020). 'Making do' with soft authoritarianism in pre-genocide Rwanda. Comparative Politics, 52(4), 557-579.

Diamant, N. J. (2001). Making love 'legible' in China: Politics and society during the enforcement of civil marriage registration, 1950-66. Politics and Society, 29(3), 447-480. 
Emigh, R. J., Ahmed, P., \& Riley, D. (n.d.). Puerto Rico: How everyday forms of categorization survived imperialist censuses. Forthcoming.

Emigh, R. J., Riley, D., \& Ahmed, P. (2016). Changes in censuses from imperialist to welfare states: How societies and states count (Vol. 2). Basingstoke: Palgrave Macmillan.

Emigh, R. J., Riley, D., \& Ahmed, P. (2019). Toward a sociology of knowledge and land surveys: The influence of societies and states. Journal of Historical Sociology, 32, 404-425.

Fox, N., \& Brehm, H. N. (2018). "I decided to save them": Factors that shaped participation in rescue efforts during genocide in Rwanda. Social Forces, 96(4), 1625-1648.

Francis, A. M., \& Tannuri-Pianto, M. (2015). Inside the black box: Affirmative action and the social construction of race in Brazil. Ethnic and Racial Studies, 38, 2771-2790.

Fujii, L.-A. (2009). Killing neighbors: Webs of violence in Rwanda. Ithaca, NY: Cornell University Press.

Goldberg, D. T. (1997). Taking stock: Counting by race. In D. T. Goldberg (Ed.), Racial subjects: Writing on race in America (pp. 27-58). New York, NY: Routledge.

Gourevitch, P. (1996). After genocide: A conversation with Paul Kagame. Transitions,72, 162-194.

Guichaoua, A. (2015). From war to genocide: Criminal politics in Rwanda, 1990-1994 (D. E. Webster, Trans.). Madison, WI: University of Wisconsin Press.

Hacking, I. (1986). Making up people. In T. Heller, M. Sosna, \& D. Wellbery (Eds.), Reconstructing individualism: Autonomy, individuality, and the self in western thought (pp. 222236). Stanford, CA: Stanford University Press.

Howe, G., \& McKay, A. (2007). Combining quantitative and qualitative methods in assessing chronic poverty: The case of Rwanda. World Development, 35(2), 197-211.

Ingelaere, B. (2016). Inside Rwanda's Gacaca courts: Seeking justice after genocide. Madison, WI: University of Wisconsin Press.

Jenkins, R. (1997). Rethinking ethnicity: Arguments and explorations. London: SAGE.

Kagame, P. (2009). Preface. In P. Clark \& Z. D. Kaufman (Eds.), After genocide: Transitional justice, post-conflict reconstruction and reconciliation in Rwanda and beyond. New York, NY: Columbia University Press. 
Kertzer, D. I., \& Arel, D. (2002). Censuses, identity formation, and the struggle for political power. In D. I. Kertzer \& D. Arel (Eds.), Census and identity: The politics of race, ethnicity, and language in national censuses (pp. 1-42). Cambridge: Cambridge University Press.

Kimonyo, J. P. (2019). Transforming Rwanda: Challenges on the road to reconstruction. Boulder, $\mathrm{CO}$ and London: Lynne Rienner Publishers.

Kinzer, S. (2007). Rwanda’s big gamble. New York Review of Books, March 29.

Kotkin, S. (1995).Magnetic mountain: Stalinism as a civilization. Berkeley, CA: University of California Press.

Lam, T. (2011). A passion for facts: Social surveys and the construction of the Chinese nationstate, 1900-1949. Berkeley, CA: University of California Press.

Lemarchand, R. (1970). Rwanda and Burundi. Santa Barbara, CA: Praeger.

Lemarchand, R. (2018). Reconsidering France's role in the Rwandan genocide. Africa is a country. Retrieved from https://africasacountry.com/2018/06/reconsidering-frances-role-in-therwandan-genocide/. Accessed on July 14, 2020.

Lieberman, E. S., \& Singh, P. (2012). The institutional origins of ethnic violence. Comparative Politics, 45,1-24.

Lieberman, E. S., \& Singh, P. (2017). Census enumeration and group conflict: A global analysis of the consequences of counting. World Politics, 69,1-53.

Longman, T. (2017). Memory and justice in post-genocide Rwanda. Cambridge: Cambridge University Press.

Loveman, M. (2005). The modern state and the primitive accumulation of symbolic power. American Journal of Sociology, 110(6), 1651-1683.

Loveman, M. (2007). Blinded like a state: The revolt against civil registration in nineteenth century Brazil. Comparative Studies in Society and History, 49(1), 5-39.

Loveman, M. (2014). National colors: Racial classification and the state in Latin America. Oxford: Oxford University Press.

Loyle, C. E., \& Davenport, C. (2015). Transitional injustice: Subverting justice in transition and postconflict societies. Journal of Human Rights, 15(1), 126-149. 
Luft, A. (2015). Toward a dynamic theory of action at the micro level of genocide: Killing, desistance, and saving in 1994 Rwanda. Sociological Theory, 33(2), 148-172.

Luft, A. (2019a). Dehumanization and the normalization of violence: It's not what you think. Social Science Research Council: Items. Retrived from https://items.ssrc.org/dehumanizationand-thenormalization-of-violence-its-not-what-you-think/. Accessed on May 22, 2019.

Luft, A. (2019b). The contribution of social movement theory to understanding genocide: Evidence from Rwanda. Contention: The Journal of Social and Political Protest, 7(2), 1-30.

Malkki, L. (1995). Purity and exile: Violence, memory and national cosmology among Hutu Refugees in Tanzania. Chicago, IL: University of Chicago Press.

Mamdani, M. (2002). When victims become killers: Colonialism, nativism and the genocide in Rwanda. Princeton and Oxford: Princeton University Press.

Marx, A. (1997). Making race and nation: A comparison of the United States, South Africa, and Brazil. Cambridge: Cambridge University Press.

Mironko, C. K. (2004). Social and political mechanisms of mass murder: An analysis of perpetrators in the Rwandan Genocide. New Haven, CT, USA.

Mora, G. C. (2014). Making hispanics: How activists, bureaucrats, and media constructed a new American. Chicago, IL: University of Chicago Press.

Nagel, J. (1995). American Indian ethnic renewal: Politics and the resurgence of identity. American Sociological Review, 60(6), 947-965.

National Unity and Reconciliation Commission. (2000). Nation-wide grassroots consultations report: Unity and reconciliation initiatives in Rwanda. Kigali: NURC. Nduwayo, L. (2002). Giti et le génocide rwandais. Paris: L Harmattan.

Newbury, C. (1988). The cohesion of oppression: Rwanda, 1860-1960. New York, NY:

Columbia University Press.

Newbury, C. (1998). Ethnicity and the politics of history in Rwanda. Africa Today, 45(1), 7-24.

Newbury, D. and C. Newbury, 2000. 'Bringing the Peasants Back In: Agrarian Themes in the Construction and Corrosion of Statist Historiography in Rwanda'. American Historical Review, 105 , no. 3, 832-77.

Paschel, T. S. (2016). Becoming black political subjects: Movements and ethno racial rights in Colombia and Brazil. Princeton, NJ: Princeton University Press. 
Pottier, J. (2002). Re-imagining Rwanda: Conflict, survival and disinformation in the late twentieth century. Cambridge: Cambridge University Press.

Prunier, G. (1995). The Rwanda crisis: History of a genocide. New York, NY: Columbia University Press.

Purdeková, A. (2011). 'Even if I am not here, there are so many eyes': Surveillance and state reach in Rwanda. Journal of Modern African Studies, 49(3), 475-497.

Purdeková, A. (2015). Making Ubumwe: Power, state and camps in Rwanda's unity-building project. New York, NY and Oxford: Berghahn Books.

Purdeková, A. (2016). 'Mundane sights' of power: The history of social monitoring and its subversion in Rwanda. African Studies Review, 59(2), 59-86.

Reyntjens, F. (2013). Political governance in post-genocide Rwanda. Cambridge: Cambridge University Press.

Reyntjens, F. (2018). Understanding Rwandan politics through the longue dur'ee: From the precolonial to the post-genocide era. Journal of Eastern African Studies, 12(3), 514-532.

Rodríguez-Muñiz, M. (2017). Cultivating consent: Nonstate leaders and the orchestration of state legibility. American Journal of Sociology, 123(2), 385-425.

Rodríguez-Muñiz, M. (2021). Figures of the future: Atino civil rights and the politics of demographic change. Princeton, NJ: Princeton University Press.

Russell, S. G., \& Carter, P. L. (2019). When the past is in the present: The paradox of educational opportunity and social inclusion in South Africa and Rwanda. Sociology of Race and Ethnicity, 5(4), 547-561.

Scott, J. (1990). Domination and the arts of resistance: Hidden transcripts. New Haven, CT and London: Yale University Press.

Scott, J. (1998). Seeing like a state: How certain schemes to improve the human condition have failed. New Haven, CT and London: Yale University Press.

Star, S. L., \& Lampland, M. (2009). Reckoning with standards. In M. Lampland \& S. L. Star (Eds.), Standards and their stories: How quantifying, classifying, and formalizing practices shape everyday life (pp. 3-33). Ithaca, NY: Cornell University Press.

Starr, P. (1987). The sociology of official statistics. In W. Alonso \& P. Starr (Eds.), The politics of numbers (pp. 5-57). New York, NY: Russell Sage Foundation. 
Starr, P. (1992). Social categories and claims in the liberal state. In M. Douglas \& D. Hull (Eds.), How classification works (pp. 154-179). Edinburgh: Edinburgh University Press.

Straus, S. (2004). How many perpetrators were there in the Rwandan genocide: An estimate. Journal of Genocide Research, 6(1), 85-98.

Straus, S. (2006). The order of genocide: Race, power and war in Rwanda. Ithaca, NY: Cornell University Press.

Thomson, S. (2010). Getting close to Rwandans since the genocide: Studying everyday life in highly politicized research settings. African Studies Review, 53(3), 19-34.

Thomson, S. (2011). The darker side of transitional justice: The power dynamics behind Rwanda's Gacaca courts. Africa, 81(3), 373-390.

Thomson, S. (2013). Whispering truth to power: Resistance to reconciliation in post-genocide Rwanda. Madison, WI: University of Wisconsin Press.

Thomson, S. (2017). The long shadow of genocide in Rwanda. Current History, 116(790), 183188. Thomson, S. (2018). Rwanda: From genocide to precarious peace. New Haven, CT and London: Yale University Press.

Thomson, S. (2020). Settler genocide in Rwanda? Colonial legacies of everyday violence. In M. Adhikari (Ed.), Settler colonialism and genocide: Reflections on the role of civilians in driving exterminatory violence (pp. 241-265). Cape Town: University of Cape Town Press.

Tilly, C. (1990). Coercion, capital, and European states, a.d. 990-1992. Cambridge: Cambridge University Press.

Tilly, C. (2004). Social boundary mechanisms. Philosophy of the Social Sciences, 34, 211-236.

Uvin, P. (1998). Aiding violence: The development enterprise in Rwanda. Hartford, CT: Kumarian Press.

Vansina, J. (2004). Antecedents to modern Rwanda: The Nyiginya Kingdom. Madison, WI: University of Wisconsin Press.

Wacquant, L. (2002). From slavery to mass incarceration: Rethinking the 'race question' in the US. New Left Review, 13,41-60.

Wacquant, L. (1997). Towards an analytic of racial domination. Political Power and Social Theory, 11, 221-234. 
Wagner, P., \& Sawyer, W. (2018). States of incarceration: The global context 2018. Retrieved from https://www.prisonpolicy.org/global/2018.html. Accessed on May 14, 2019.

Waldorf, L. T. (2006). Mass justice for mass atrocity: Transitional justice and illiberal peacebuilding in Rwanda. PhD dissertation, Irish Centre for Human Rights, Faculty of Law, University of Galway, Galway.

Wedeen, L. (1999). Ambiguities of domination: Politics, rhetoric, and symbols in contemporary Syria. Chicago, IL: University of Chicago Press. 
